\title{
Dysplastic conditions of the right ventricular myocardium: Uhl's anomaly $v$ arrhythmogenic right ventricular dysplasia
}

Department of Paediatrics, National Heart and Lung Institute, London L M Gerlis $S$ Yen Ho

$\mathrm{R} \mathrm{H}$ Anderson

Department of Paediatrics and Paediatric Cardiology, University of Heidelberg, Germany S C Schmidt-Ott

Correspondence to: Dr L M Gerlis, Departmen of Paediatrics, National Heart and Lung Institute, Dovehouse Street, London SW3 6LY.

Accepted for publication 22 June 1992.

Leon M Gerlis, Séverine C Schmidt-Ott, Siew Yen Ho, Robert H Anderson

\begin{abstract}
Objective-Since 1905 there have been many reports of cases in which the right ventricle was deficient in myocardium. Several terms have been used to describe this condition. Of these, "Uhl's anomaly" and "arrhythmogenic right ventricular dysplasia" are most often used. Our study investigates the relation between these entities.
\end{abstract}

Method-Five cases with a primary deficiency of the right ventricular musculature were examined. The findings were compared with those published reports to evaluate the similarities and differences between Uhl's anomaly and arrhythmogenic dysplasia.

Results-The five cases showed two patterns of myocardial deficiency in the right ventricle. On the one hand, the parietal wall was paper thin with complete absence of musculature and apposition of the endocardial and epicardial layers. On the other hand, patchy, localised fibrofatty tissue replacement was found within the parietal musculature. Evidence from our cases, combined with analysis of other publications, showed different modes and timing of clinical presentation of the patients with these two anatomical conditions, congestive heart failure or arrhythmia.

Conclusions-The conditions variously described as Uhl's anomaly and arrhythmogenic dysplasia are separate and distinct morphological entities.

(Br Heart J 1993;69:142-150)

As far as we can find, it was Osler who first referred to a parchment heart in which all the cardiac chambers were greatly dilated and the walls very thin. ${ }^{1}$ Then, in 1952 , Uhl described a case in which the wall of the right ventricle was said to be paper thin and almost devoid of muscle fibres, an appearance akin to parchment heart. ${ }^{2}$ Since then, many examples have been reported in which the muscle of the right ventricle was wholly or partly deficient. The term Uhl's anomaly has generally been applied to such cases, although other terms have been used such as ectasia of the right ventricle, ${ }^{3}$ congenital aplasia of the right ventricular myocardium, ${ }^{4}$ congenital hypoplasia of the right ventricle, ${ }^{5}$ idiopathic right ventricular myocardial dysplasia, ${ }^{6}$ absence of right ventricular myocardium, ${ }^{7}$ fatty infiltration, ${ }^{89}$ or lipomatosis. ${ }^{10}$ Then, in 1979, Fontaine et al described an entity which they called arrhythmogenic right ventricular dysplasia. ${ }^{11}$ This lesion was characterised by localised deficiency or fibrofatty tissue replacement of right ventricular myocardium. Since then, the term arrhythmogenic, or right ventricular, dysplasia, has been used increasingly often, whereas, perhaps surprisingly, references to parchment heart have ceased and those to Uhl's anomaly have noticeably decreased. This raises the question of whether these lesions represent two different entities or are simply variants of a single underlying congenital malformation? Our attention was attracted to this correlation by examination of five hearts examined at necropsy. We have supplemented our personal findings with attention to the key features of nearly 500 of the cases reported. Together, this has permitted us to evaluate the similarities and differences between these two groups of conditions.

\section{Case reports}

CASE 1

Case 1 was a male neonate for whom no clinical particulars were available. The right ventricle was paper thin and, apart from the apical trabeculations, the free wall was devoid of myocardium (fig 1). Histological examination confirmed the absence of muscle, a thin layer of elastic and fibrous tissue being all that separated the epicardium and the endocardium (table 1). The left ventricle, great arteries, and coronary vessels were normal.

CASE 2

Case 2 was a newborn child. No clinical details were available. The right ventricle was considerably dilated and the free wall of the outflow tract was paper thin, transillumination suggesting it to be devoid of musculature (fig 2 , table 1). The apical portion of the free wall was also thin, but showed interlacing muscular trabeculations. The tricuspid valve had normal leaflets but the papillary muscles were atrophic. Histological examination showed that the affected portion consisted of fibrous tissue with endocardium on one aspect and epicardium on the other. There were no myocardial fibres, but the wall was permeated by fine elastic fibres. No 


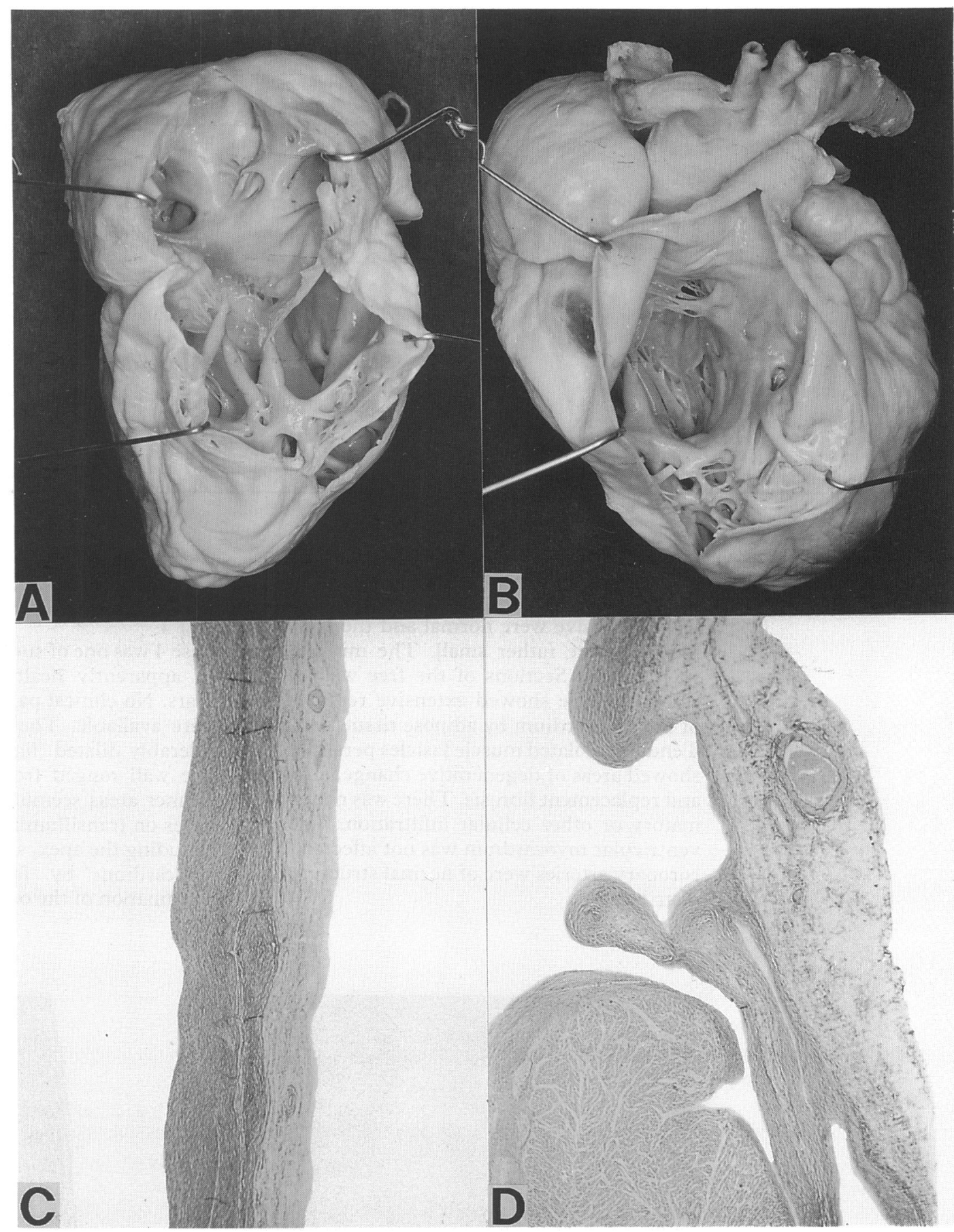

Figure 1 Case 1: neonatal male. (A) The right side of the heart is opened laterally to show the normal atrial wall, the atrophic ventricular wall and the small papillary muscles. The leaflets of the tricuspid valve are normal. (B) The right ventricle is opened anteriorly to show the paper thin wall of the outlet region and the attenuated apical septomarginal trabeculations and supraventricular crest. (C) Section of the anterior wall of the right ventricle. The muscle fibres have been completely replaced by fibrous tissue which contains many fine elastic fibres $(\times 25)$. Elastic and van Gieson stain. (D) Another area showing well preserved muscle in the trabeculations but complete absence in the parietal wall that is composed of little more than endocardium and epicardium. Note the normal coronary vessels. $\times$ 50; elastic and van Gieson stain.

inflammatory cells were noted and no fatty tissue was present within the attenuated area. The left side of the heart was normal, as were the great arteries and the coronary vessels.

CASE 3

Case 3 was a male 16 yrs old at death. This apparently healthy boy collapsed suddenly while walking home from school. He was taken to hospital immediately, but was dead on arrival. There was no significant family history of cardiac disease or of sudden death.

No abnormalities were noted at postmortem examination apart from the enlarged heart, which weighed $390 \mathrm{gm}$. The right ventricle was grossly dilated and the free wall showed considerable thinning with many areas completely devoid of myocardium, with adipose tissue occupying the space between the endocardium and epicardium (fig 3). The leaflets of the 
Table 1 Summary of the five cases

\begin{tabular}{|c|c|c|c|c|c|c|c|c|c|c|}
\hline \multirow[b]{2}{*}{ Case } & \multirow[b]{2}{*}{ Age } & \multirow[b]{2}{*}{ Sex } & \multirow[b]{2}{*}{ Presentation } & \multirow[b]{2}{*}{ Previous symptoms } & \multicolumn{5}{|c|}{ Macroscopic findings ( $R V)$} & \multirow[b]{2}{*}{$\begin{array}{l}\text { Microscopy findings } \\
(R V) \text { (lack of) }\end{array}$} \\
\hline & & & & & Inlet & Apical & Outlet & Septum & $\begin{array}{l}\text { Papillary } \\
\text { muscles }\end{array}$ & \\
\hline 1 & NB & $\mathbf{M}$ & Cardiac failure & - & +++ & + & +++ & + & + & $\begin{array}{l}\text { Muscle absence } \\
\text { Elastic tissue } \\
\text { Fibrous tissue } \\
\text { Inflammatory cells }\end{array}$ \\
\hline 2 & NB & $?$ & Cardiac failure & - & + & ++ & +++ & ++ & ++ & $\begin{array}{l}\text { Muscle absence } \\
\text { Fibrous replacement } \\
\text { Elastic tissue } \\
\text { Inflammatory cells }\end{array}$ \\
\hline 3 & $16 \mathrm{yr}$ & $M$ & Sudden death & 2 episodes of fainting & + & ++ & ++ & ++ & ++ & $\begin{array}{l}\text { Fatty muscle replacement } \\
\text { Fibrous replacement } \\
\text { Myocardial degenerative } \\
\text { changes } \\
\text { Inflammatory cells }\end{array}$ \\
\hline 4 & $22 \mathrm{yr}$ & $\mathbf{M}$ & Sudden death & - & + & ++ & +++ & ++ & ++ & $\begin{array}{l}\text { Fibrous and fatty } \\
\text { replacement } \\
\text { Fatty infiltration }\end{array}$ \\
\hline 5 & $36 \mathrm{yr}$ & $\mathbf{M}$ & $\begin{array}{l}\text { Arrhythmia and } \\
\text { cardiac failure }\end{array}$ & $\begin{array}{l}\text { Exhaustion, irregular } \\
\text { pulse from age of } 5 \mathrm{yr}\end{array}$ & ++ & ++ & +++ & + & ++ & $\begin{array}{l}\text { Inflammatory cells } \\
\text { Muscle deficiency and } \\
\text { atrophy } \\
\text { Fibrous and fatty tissue } \\
\text { Inflammatory cells }\end{array}$ \\
\hline
\end{tabular}

RV, right ventricle; NB, new born; $M$, male.

tricuspid valve were normal and the papillary muscles were rather small. The mitral valve was normal. Sections of the free wall of the right ventricle showed extensive replacement of the myocardium by adipose tissue (table 1). Tenuous, isolated muscle fasicles persisted and showed areas of degenerative change, atrophy, and replacement fibrosis. There was no inflammatory or other cellular infiltration. The left ventricular myocardium was not affected. The coronary arteries were of normal structure and distribution.

\section{CASE 4}

Case 4 was one of sudden collapse and death in an apparently healthy young man aged 22 years. No clinical particulars or family history were available. The right ventricle was considerably dilated (fig 4). The thickness of the free wall ranged from 1 to $4 \mathrm{~mm}$, with the thinner areas seeming to be devoid of muscle fibres on transillumination (fig 4). Other areas including the apex, showed replacement of the myocardium by fatty tissue. Histological examination of the outflow tract (fig 4 , table 1 )

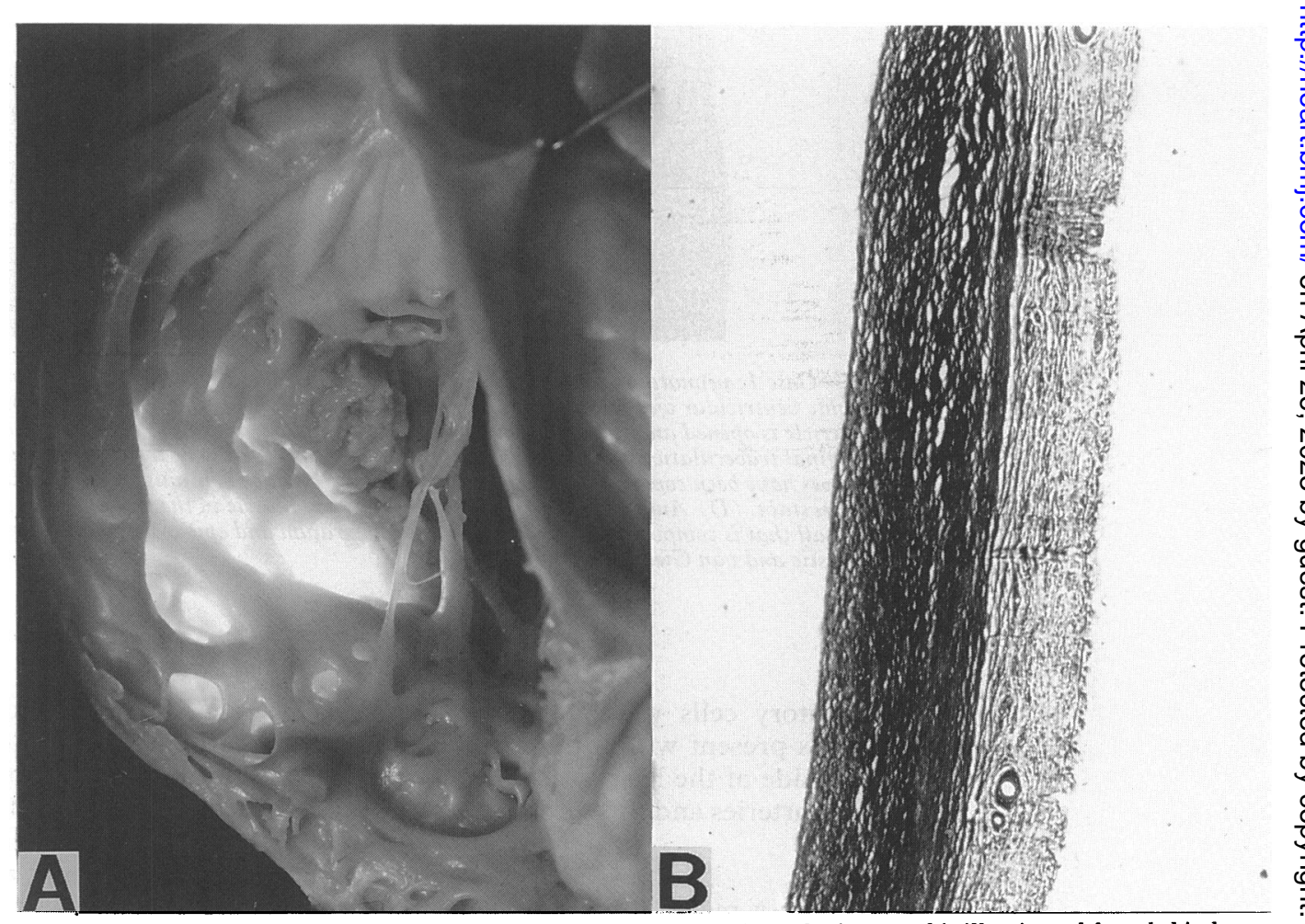

Figure 2 Case 2: neonate. (A) The right ventricle has been opened from the front and is illuminated from behind, showing the very thin and translucent free wall. Apical trabeculations are present and the papillary muscles are atrophic. $(B)$ Section of the right ventricle showing replacement of the muscle layer by fibrous tissue $(\times 25)$. Elastic and van Gieson stain. 


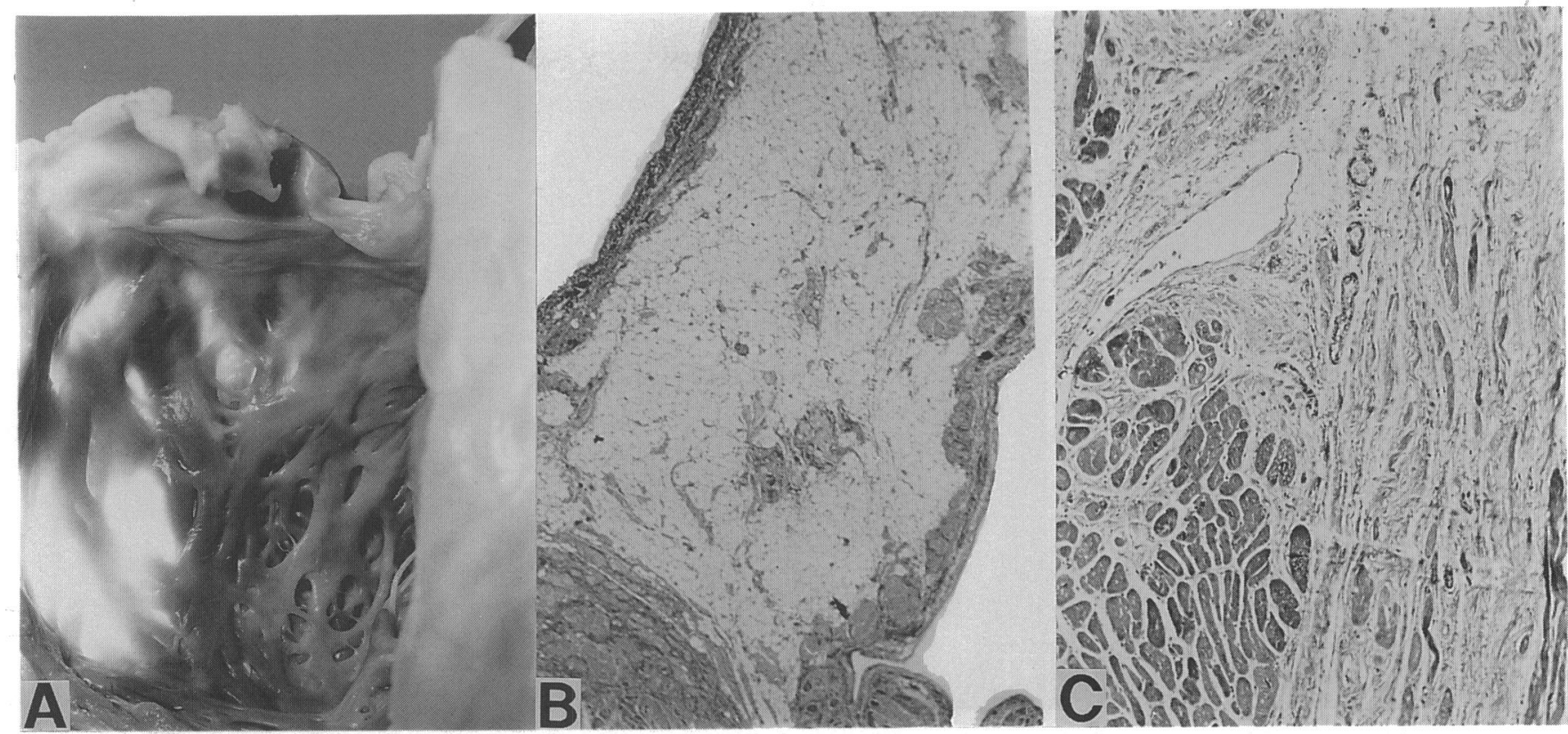

Figure 3 Case 3: male aged 16 years. (A) The interior of the right ventricle transilluminated from behind, showing deficiency of musculature in the posterior free wall. $(B)$ Section of the anterior free wall showing an area of almost complete replacement of the myocardium by adipose tissue ( $\times 25)$. Haematoxylin and eosin stain. (C) Section of the apical region of the right ventricle showing surviving trabecular myocardium in the upper left portion. Elsewhere the myocardial fibres are atrophic and degenerate and are widely separated by replacement fibrosis $(\times 100)$. Masson's trichrome stain.

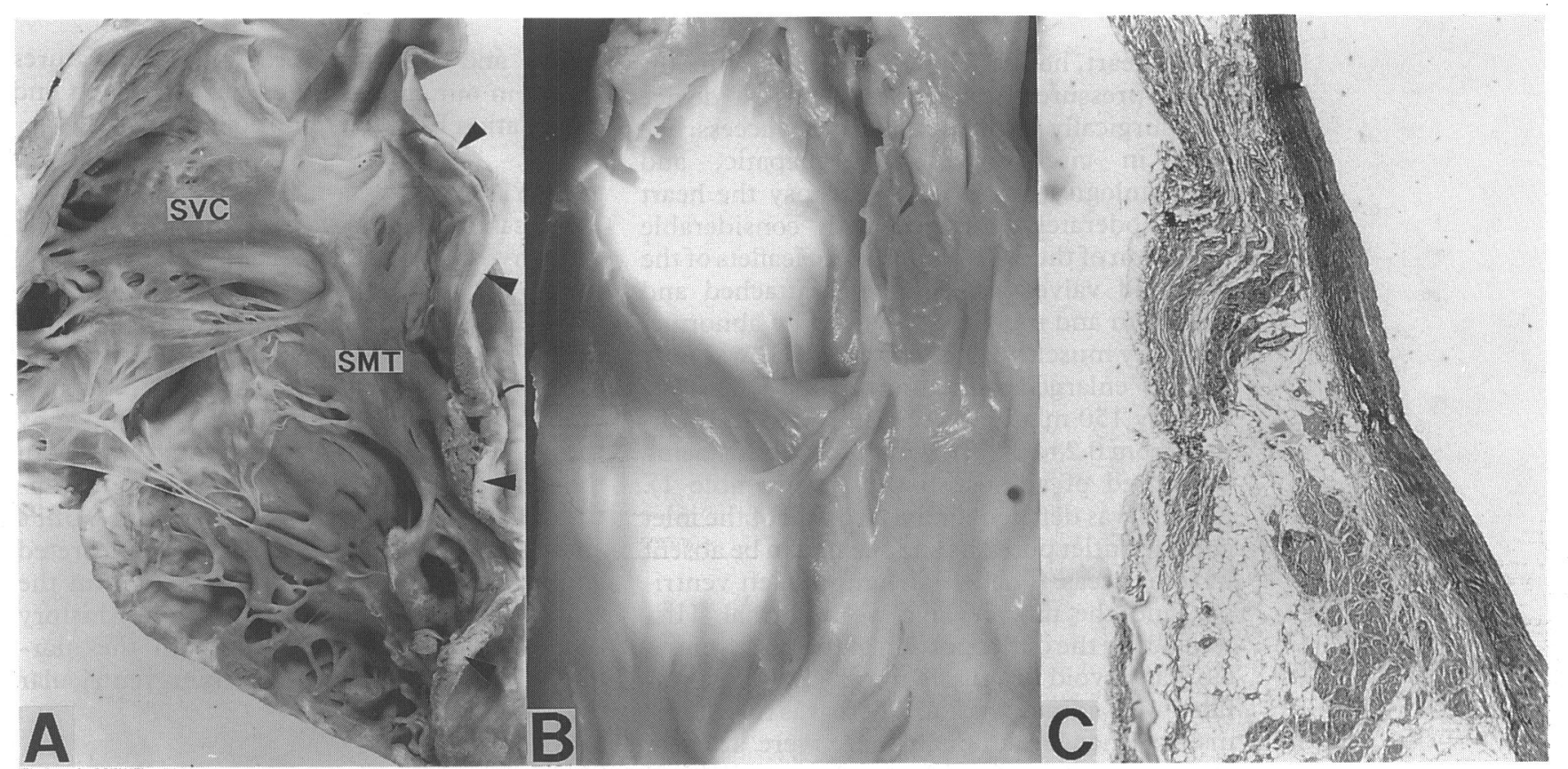

Figure 4 Case 4: man aged 22 years. (A) The right ventricle is opened anteriorly to show the thin wall of the outflow tract (arrow heads), hypoplastic supraventricular crest (SVC), septomarginal trabeculation (SMT) and papillary muscles. (B) The wall of the outflow tract is transilluminated to show extensive areas of muscle loss. (C) Section of the wall of the outlet showing fibrous replacement of the myocardium in the upper portion. Scattered muscle fibres infiltrated with adipose tissue persist in the lower portion $(\times 25)$. Elastic and van Gieson stain.

showed areas without muscle fibres, again with replacement by fibrofatty tissue. Adjacent muscle fibres were widely separated by adipose tissue. There was some interstitial fibrosis but no evidence of inflammation. Elsewhere the right ventricular muscle appeared to be normal.

CASE 5

Case 5 was a man aged 36 years at death. There was no relevant family history. Childhood had been normal up to the age of five years, after which he became unduly fatigued during exer- tion. He had been conscious of palpitations and a racing pulse from time to time over 15 years before death. Treatment with antiarrhythmic drugs did not stabilise his rhythm completely. Nine months before he died severe weakness, oedema, and ascites developed. Cardiac catherisation showed a mean pressure of $24 \mathrm{~mm} \mathrm{Hg}$ in the right atrium, right ventricle, and pulmonary arteries. The right atrium was enormously enlarged and the right ventricle was dilated and poorly contracting. The left ventricular function was normal. He was diagnosed as having Uhl's anomaly. While awaiting transplantation 


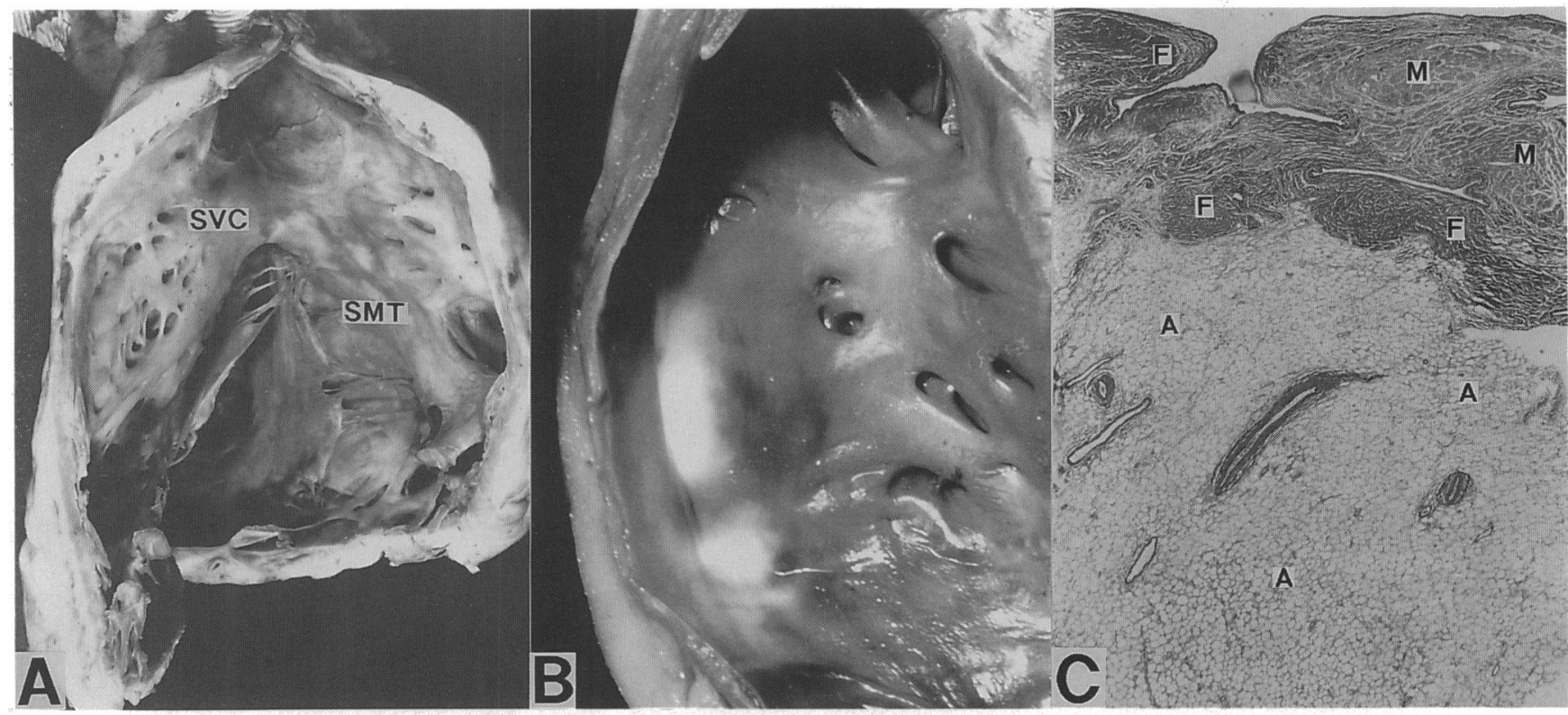

Figure 5 Case 5: man aged 36 years. (A) Right ventricle opened anteriorly showing the thin wall largely composed of adipose tissue with hypoplasia of the supraventricular crest (SVC) and septomarginal trabeculation (SMT). (B) A closer view of part of the outflow tract that has been transilluminated to show deficiency of myocardium. (C) Section of the wall of the right ventricle that is composed of adipose tissue $(A)$, fibrous tissue $(F)$ and small groups of surviving muscle $(M)(\times 25)$. Elastic and van Gieson stain.

of the heart, he suddenly deteriorated with low blood pressure. A biventricular assist device was surgically implanted without success. He died in circulatory, renal, hepatic, and haematological failure. At necropsy the heart was moderately enlarged with considerable dilatation of the right atrium. The leaflets of the tricuspid valve were normally attached and were thin and mobile, supported by abnormal papillary muscles. The right ventricle was only slightly enlarged with an estimated volume of roughly $150 \mathrm{ml}$. The free wall varied in thickness from $0 \cdot 2$ to $0 \cdot 8 \mathrm{~cm}$, with most of this being composed of adipose tissue (fig 5, table 1). Muscle was deficient in the free wall of the inlet and the outlet portions and seemed to be absent in some areas. The left atrium, the left ventricle, and the mitral valve were normal. Histologically the outlet portion of the right ventricle was devoid of muscle fibres. This area was filled with adipose tissue. There was no inflammatory change, although there were areas of replacement fibrosis with atrophy of individual muscle fibres.

\section{Discussion}

We have described five cases showing two patterns of deficiency of the myocardium of the right ventricle. Two cases represent a condition identical to that described by Uhl. ${ }^{2}$ The other three are comparable with those described in publications as arrhythmogenic right ventricular dysplasia (or right ventricular cardiomyopathy). ${ }^{12}$ In terms of morphology, these entities are unequivocally distinct. Understanding of each lesion, none the less, seems to have been confused in recent years by imprecise use of the term Uhl's anomaly, as several cases with morphology directly comparable with that seen in our last three cases have been described as Uhl's anomaly. ${ }^{1314}$ We have, therefore, com- pared and contrasted the various features found in our cases with earlier reports to find the relation between these conditions.

\section{FAMILY HISTORY}

Most cases described of either Uhl's anomaly or arrhythmogenic right ventricular dysplasia have been sporadic. There are, none the less, some reports quoting a history of familial occurrence. This is generally in siblings, but extends in some instances through three generations. Analysis of this material is clouded by the fact discussed above, namely that cases with the morphology of arrhythmogenic right ventricular dysplasia have been described as Uhl's anomaly. ${ }^{12-32}$ When the cases are reinterpreted and graded, as far as can be done within the scope of our investigation, then a family history is mainly restricted to cases with the morphology of arrhythmogenic right ventricular dysplasia.

\section{SEX}

An analysis of 481 cases from 117 publications specified 220 males and 111 females, giving a male: female sex ratio of $2: 1$. The sex was not mentioned in a further 150 cases. In 84 cases specified as being Uhl's anomaly (or parchment heart), there were $42(56 \%)$ males and 33 $(44 \%)$ females, or a ratio of $1 \cdot 27: 1 \cdot 0$. In the 397 cases referred to as arrhythmogenic dysplasia, or similar there were $178(70 \%)$ males and 78 $(30 \%)$ females, a ratio of $2 \cdot 28: 1 \cdot 0$. The different degree of male predominance is significant.

AGE

Of 193 published cases in which the age was stated, it ranged from one day to 84 years. In those specified as Uhl's anomaly, there was a considerably higher prevalence in the young when compared with those described as being 
Table 2 References specifiying Uhl's anomaly or parchment heart reclassified according to our criteria (surname of first author only is listed)

\begin{tabular}{|c|c|c|}
\hline True Uhl's anomaly & $A R V D$ & Insufficient data \\
\hline $\begin{array}{l}\text { Aherne } e^{49} \\
\text { Ando }^{50} \\
\text { Arcilla }^{51} \\
\text { Auzepy }^{52} \\
\text { Buonanno }^{53} \\
\text { Calabro }^{54} \\
\text { Cote }^{5} \\
\text { Cumming }^{4} \\
\text { Descalzo }^{55} \\
\text { Diaz }^{56} \\
\text { Fuertes }^{57} \\
\text { Galal }^{41} \\
\text { Gasul }^{58} \\
\text { Haworth } \\
\text { Ibsen }^{60} \\
\text { Kaul }^{61} \\
\text { Kinare }^{62} \\
\text { Leproie }^{63} \\
\text { Montella }^{64} \\
\text { Neimannn }^{65} \\
\text { Novak }^{66} \\
\text { Osler }^{1} \\
\text { Perrin }^{67} \\
\text { Segall }^{68} \\
\text { Sherman }^{69} \\
\text { Tatibouet }^{70} \\
\text { Taussig } \\
\text { Uhl }^{29} \\
\text { Wager }^{33} \\
\text { Zuberbuhler }^{71}\end{array}$ & 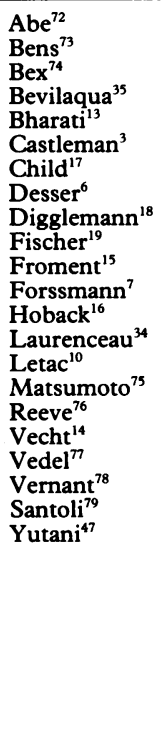 & $\begin{array}{l}\text { Castellis }^{80} \\
\text { Drory }^{81} \\
\text { Dupont }^{82} \\
\text { Esposittos }^{83} \\
\text { French }^{84} \\
\text { Morand }^{85} \\
\text { Obma }^{86} \\
\text { Ostermeyer }^{87} \\
\text { Rashkind }^{88} \\
\text { Sugiura }^{89} \\
\text { Tadei i }^{90} \\
\text { Wagner }^{91}\end{array}$ \\
\hline
\end{tabular}

ARVD, arrhythmogenic right ventricular dysplasia. This is not presented as a complete bibliography.

due to arrhythmogenic dysplasia. The earliest documented abnormalities were noted on echocardiography in a 24 week fetus, but no definite diagnosis was made at that time. ${ }^{33}$ This striking difference in the age at presentation becomes even more obvious when published cases described as Uhl's anomaly but having the anatomical features of arrhythmogenic right ventricular dysplasia, are reclassified (table 2).

\section{MODE OF CLINICAL PRESENTATION}

There were two main modes of clinical presentation: congestive heart failure and arrhythmia. In making our analysis of published work, we assigned arrhythmic presentation to those patients presenting as palpitation, syncope, ventricular tachycardias, or sudden death. Congestive heart failure was by far the most common occurrence in the cases specified as exhibiting Uhl's anomaly, particularly when we excluded those named in this fashion but having the morphology of arrhythmogenic right ventricular dysplasia. This was largely associated with a higher proportion of young patients.

\section{EXERCISE INDUCED DEATHS}

Some cardiac arrhythmia is the usual mode of presentation in cases of arrhythmogenic dysplasia. It also features in those cases described initially as Uhl's anomaly, but which have the morphology we have associated with arrhythmogenic right ventricular dysplasia. The arrhythmia is frequently exercise induced and may produce palpitations or syncope. Sometimes the first attack may be fatal. A number of cases of sudden death during athletic activity have been attributed to right ventricular myocardial deficiency. ${ }^{12} 151623263134-38$ In many cases there may be a retrospective history of previous episodic symptoms during exertion. ${ }^{12}$ Corrado and his colleagues found myocardial abnormalities of the right ventricle to be the most frequent cause of sudden death in young competitive athletes, accounting for six out of their 22 cases. $^{38}$

\section{ASSOCIATED ANOMALIES}

The original case of Uhl had no additional intracardiac lesions. Indeed, Taussig stated subsequently that the diagnosis should not be made in the setting of associated lesions. ${ }^{39}$ There is no reason why the described condition cannot coexist with other anomalies. Thus O'Connor and his colleagues described histologically proved areas of total absence of myocardium in a recent study of cases with pulmonary atresia and intact septum. ${ }^{40}$ Of the 481 cases reviewed, we have found mention of associated cardiac malformations in 17. In 10 of these, the associated lesion was pulmonary atresia, but not in the form described by O'Connor et al. ${ }^{40}$ It is always questionable whether the dilatation and thinning of the wall of the right ventricle seen more typically in pulmonary atresia with intact ventricular septum is due primarily to a primary myocardial dysplasia or, more probably, is secondary to the lesions afflicting the pulmonary and tricuspid valves. In selecting our cases for comparison, therefore, we excluded cases with pulmonary atresia, and similarly excluded cases where aortic atresia was found in association with discordant ventriculoarterial connections. ${ }^{41}$

There remained six cases with associated lesions, an incidence of $1.4 \%$. This is only fractionally higher than the overall incidence of congenital cardiac malformation in live births ${ }^{42}$ and can easily be explained on the basis of chance association.

\section{MORPHOLOGICAL APPEARANCES}

Our review of the literature shows that the term Uhl's anomaly has frequently been used to describe cases that now would be considered as examples of arrhythmogenic right ventricular dysplasia. When we take note of this practice it is clear that, as exemplified by our cases, there is a clearcut morphological difference between the two entities. In the lesion that we term Uhl's anomaly, represented by the first two cases in our material and directly comparable with the index case, there is virtually complete absence of the myocardium of the parietal wall of the right ventricle. The septal component, however, along with the ramifications of the septomarginal trabeculation and the papillary muscles of the tricuspid valve, are normally muscularised. The parietal wall, by contrast, is composed of the opposing endocardial and epicardial ventricular surfaces, with no fatty tissue interposed between these layers. These changes are truly congenital, being present at birth and diagnosed now by fetal echocardiography. ${ }^{33}$ We have also been shown a necropsied fetal specimen in which the lesion was directly comparable to the initial description of Uhl (courtesy of Dr Jane Zucollo, University of Nottingham). 
By contrast with this total absence of the myocardium in classical Uhl's malformation, arrhythmogenic right ventricular dysplasia is characterised by patchy and localised replacement of the parietal wall of the right ventricle by fibrofatty tissue. This adipose replacement occurs primarily within the ventricular outflow tract, but can also be seen in the inlet or apical regions, sometimes spreading to involve the left ventricle. The adipose replacement in cases such as those shown in our material is sufficiently obvious to be visible to the naked eye. These gross morphological appearances are those described by French workers as arrhythmogenic right ventricular dysplasia, and by Italian workers as right ventricular cardiomyopathy. ${ }^{434}$ The question remaining to be answered, and one to which we cannot contribute, is how much fatty replacement is necessary to justify the diagnosis of cardiomyopathy, because some degree of adipose tissue is a ubiquitous constituent of the right ventricular wall. ${ }^{45}$

Irrespective of that consideration the appearances noted in our study permit a clear distinction to be made between Uhl's anomaly on the one hand and arrhythmogenic right ventricular dysplasia or right ventricular cardiomyopathy on the other. The choice between the last terms would, at present, seem a matter of personal preference.

\section{AETIOLOGY AND PATHOGENESIS}

Uhl speculated that the primary congenital defect was failure of development of the muscle of the primordium of the right ventricle, which he considered to be derived from the right sided element of the paired primitive myoendocardial tubes in the very early embryo. ${ }^{2}$ Dalla Volta considered that the right ventricle was particularly susceptible to injury during intrauterine life as it was submitted to greater pressures and resistances than the left ventricle, but did not mention the nature of the precipitating factor. ${ }^{46}$

In our cases, as well as in those published elsewhere, we have been impressed by one constant morphological feature. In both Uhl's anomaly and right ventricular dysplasia the degree of deficiency of muscle is maximal in the outlet region and minimal in the inlet region. This has suggested the possibility of a longitudinal rather than a lateral orientation or developmental defect. The heart can be considered to be derived from a primitive tube, the subsequent folding and looping of which produces the various definitive chambers. The ventricular loop comprises proximal and distal limbs that form the major portions of the left and right ventricles respectively. Thus the ventricles can be considered as having a serial origin. Selective maldevelopment of the myocardial mantle in the distal or arterial end of the primitive cardiac tube could, to a greater or lesser extent, produce the spectrum of abnormalities under discussion.

Although Uhl's anomaly and arrhythmogenic right ventricular dysplasia are distinct morphological entities, it is possible that they might share a common pathogenesis. Familial incidence, especially in arrhythmogenic right ventricular dysplasia, may be due to a common exposure to toxic or infectious agents ${ }^{23}$ but a genetic anomaly would seem to be a more likely explanation for the appearance of the condition through three generations. ${ }^{27} 31$ It has been considered that this may be due to an autosomal recessive condition ${ }^{1925}$ or, more probably, to one of autosomal dominance with incomplete penetrance. $^{23}$

In Uhl's anomaly it seems that the distal part of the primitive ventricular myocardial mantle does not develop. The endocardial and epicardial layers, therefore, remain in contact with each other, with no residual muscle to initiate or sustain an arrhythmia. Patchy non-development of muscle, together with progressive degenerative changes in adjacent surviving muscle, may allow extended survival into adolescence or adult life and present the clinical picture of arrythmogenic right ventricular dysplasia. It may well be that the process could extend further backwards into the proximal limb of the loop, that is, the left ventricle. There is some evidence that this can occur to a minor degree. Histological changes in the myocardium of the left ventricle have been found in some cases ${ }^{21}{ }^{47}$ and clinical evidence of disturbed left ventricular function has been found in others. ${ }^{114348}$ It is likely that more extensive ventricular involvement could occur initially, but this would be incompatible with continued fetal development and would probably result in early abortion.

\section{Conclusions}

The relation of the two distinct groups described in our report has been clouded by the fact that, before recognition of arrhythmogenic right ventricular dysplasia during the 1980 s, many cases with this morphology were inaccurately classified as Uhl's malformation. Where a critical analysis is made of published work, and cases with fibrofatty tissue replacement of the parietal wall of the right ventricle are distinguished from those with congenital absence of the parietal ventricular myocardium, it becomes clear that the morphological entities are distinct. In this respect, it is also of interest to note that the mere number of cases now described as showing Uhl's malformation has fallen with the more widespread recognition and diagnosis of arrhythmogenic right ventricular dysplasia or right ventricular cardiomyopathy. There is also a case for referring to this primary disorder as right ventricular myodystrophy, in line with the dystrophies of skeletal muscle. Having made the distinction on grounds of gross morphology, our review then shows that cases of Uhl's malformation are usually diagnosed in neonatal or infant life and present with congestive heart failure. By contrast, those with arrhythmogenic right ventricular dysplasia rarely manifest symptoms before the age of 20 years, and usually present with palpitations or else die suddenly. We are unable to judge whether these last cases are best described as arrhythmogenic right ventricular dysplasia or right ventricular cardiomyopathy. The aetiology of the dysplasia, or cardio- 
myopathy is unequivocally a replacement of myocardial cells by fibrofatty tissue. The affected areas of ventricular wall show the fat filling the space initially occupied by myocardium. This is by noticeable contrast to the situation in Uhl's malformation where the afflicted wall shows no evidence of adipose tissue, the endocardial and epicardial layers being directly apposed (fig 1C).

It could be argued that the lesions are due to a similar insult, but in terms of morphology and clinical presentation they are separate and distinct entities. It therefore makes more sense to describe them by different names-Uhl's malformation and arrhythmogenic right ventricular dysplasia (or right ventricular cardiomyopathy).

We are grateful to Dr Simon Trotter who performed the necropsy, and Dr Ulrich Sigwart and Professor Sir Magdi Yacoub for permission to publish details of case 5 .

1 Osler WM. The principles and practice of medicine. 6th ed. New York: D Appleton, 1905:280.

2 Uhl HSM. A previously undescribed congenital malformation of the heart: almost total absence of the myocardium of the right ventricle. Bulletin of the Johns Hopkin Hospital 1952;91:197-209.

3 Castleman B, Towne VW. Presentation of case 38201. $N$ Engl J Med 1952;246:785-90.

4 Cumming GR, Bowman JM, Whytehead L. Congenital aplasia of the myocardium of the right ventricle (Uhl's anomaly). Am Heart J 1965;70:671-6.

5 Cote M, Davignon A, Fouron JC. Congenital hypoplasia of right ventricular myocardium (Uhl's anomaly) associated with pulmonary atresia in a newborn. Am J Cardiol 1973; w1:658-61.

6 Desser KB, Promisloff SD, Yellen LG, Benchimol A. Stress electrocardiography in Uhl's anomaly with mitral valve electrocardiography in Uhl's an
prolapse. Chest 1976;70:529-31.

7 Forssman O, Bjorkman G. Absence of the solid part of the right ventricular musculature. Acta Pathologica Microbiologica Scandinavica 1972;80:263-6.

8 Castleman B, Towne VW. Presentation of case 40411. $N$ Engl J Med 1954;251:660-4.

9 Carpenter HM. Myocardial fat infiltration. Am Heart J 1962;63:491-6.

10 Letac B, Bayot J, Barthes P. Infiltration graisseuse du coeur et maladie de Uhl. A propos d'une observation de lipomatose cardiaque. Arch Mal Coeur 1977;70:107-13.

11 Fontaine G, Guiraudon G, Frank R. Mechanism of ventricular tachycardia with and without associated chronic myocardial ischemia: surgical management based on epicardial mapping. In: Narula OS, ed. Cardiac arrhythmias. Baltimore and London: Williams and Wilkins, mias. Baltimo

12 Smeeton WMJ, Smith WM. Sudden death due to a cardiomyopathy predominantly affecting the right ventricleright ventricular dysplasia. Med Sci Law 1987;27:207-12.

13 Bharati S, Ciraulo DA, Bilitch M, Rosen KM, Lev M. Inexcitable right ventricle and bilateral bundle br
block in Uhl's disease. Circulation 1978;57:636-44.

14 Vecht RJ, Carmichael JS, Gopal R, Philip G. Uhl's anomaly Br Heart J 1979;41:676-82.

15 Froment R, Perrin A, Loire R, Dallos C. Ventricule droi papyracé du jeune adulte par dystrophie congénitale. Arch Mal Coeur 1968;61:477-503.

16 Hoback J, Adicoff A, From AHL, Smith McK, Shafer R, Chesler E. A report of Uhl's disease in identical adult twins. Chest 1981;79:306-10.

17 Child JS, Perloff JK, Francoz R, et al. Uhl's anomaly (parchment right ventricle): clinical, echocardiographic,
radionuclear, hemodynamic and angiographic features in radionuclear, hemodynamic and angiograp

18 Diggleman U, Baur HR. Familial Uhl's anomaly in adult. Am J Cardiol 1984;53:1402-3.

19 Fischer DR, Zuberbuhler JR. Familial Uhl's anomaly. $A m J$ Cardiol 1984;54:940.

20 Guiraudon GM, Klein GJ, Gulamhusein SS, et al. Tota disconnection of the right ventricular free wall: surgical treatment of right ventricular tachycardia associated with right ventricular dysplasia. Circulation 1983;67:463-70.

21 Fitchett DH, Sugrue DD, MacArthur CG, Oakley CM Right ventricular dilated cardiomyopathy. $\mathrm{Br}$ Heart 1984;51:25-9.

22 Alcasena MS, Maqueda IG, Marti JS, Orbe IC, Gamallo C, Jadraque LM. Displasia arritmogénica de ventriculo derecho y trisomia X. Presentation de un caso. Rev Esp Cardiol 1985;38:357-60.

23 Ruder MA, Winston SA, Davis JC, Abbot JA, Eldar M Scheinman MM. Arrhythmogenic right ventricular dysplasia in a family. Am J Cardiol 1985;56:799-800.

24 Kawamura O, Ohaki Y, Nakatani Y, et al. Idiopathic righ ventricular dilatation. Acta Pathol Jpn 1986;36:1693-705.
25 Moene RJ, Sobotka MA, Buis B, Bots GTAM, Elzenúa NJ. Unclassified familial cardiomyopathy with ventricular dysrhythmia. Pediatr Cardiol 1987;8:177-88.

26 Rakovec P, Rossi L, Fontaine G, Sasel B, Markez J, Voncina D. Familial arrhythmogenic right ventricular disease. $A m$ $J$ Cardiol 1986;58:377-88.

27 Laurent M, Descaves C, Biron Y, Deplace C, Almange C, Daubert J. Familial form of arrhythmogenic right ventricular dysplasia. Am Heart $J$ 1987;113:827-9.

28 Blomstroem-Lundquist $\mathrm{C}$, Enestroem S, Edvarsson N, Olsson SB. Arrhythmogenic right ventricular dysplasia presenting with ventricular tachycardia in a father and a son. Clin Cardiol 1987;10:277-85.

29 Nakanishi T, Shiroyama T, Inoue D, et al. A family study of two cases of arrhythmogenic right ventricular dysplasia with reference to genetic aspects. Kokyu To Junkan with reference to

30 Nava A, Scognamiglio $R$, Thiene $G$, et al. A polymorphic form of familial arrhythmogenic right ventricular dysplasia. Am J Cardiol 1987;59:1405-9.

31 Nava A, Thiene G, Canciani B, et al. Familial occurrence of right ventricular dysplasia. J Am Coll Cardiol 1988;12. $1222-8$

32 Sabel KG, Blomstroem-Lundquist C, Olsson SB, Enestroem S. Arrhythmogenic right ventricular dysplasia in brother and sister: Is it related to myocarditis? Pediatr Cardiol 1990;11:113-6.

33 Wager GP, Couser RJ, Edwards OP, Gmach C, Bessinger B. Antenatal ultrasound findings in a case of Uhl's anomaly. Am J Perinatol 1988;5:164-7.

34 Laurenceau JL, Lienhart JF, Malergue MC, Gilbert M, Dumesnil JG. Données échocardiographiques dans le syndrome du ventricule droit papyracé. Arch Mal Coeur 1979;72:258-62.

35 Bevilacqua G, Giusti C, Bargagna $M$. Uhl's anomaly in a young adult. Pathologica 1980;72:413-20.

36 Sigrist T, Baer W, Zink P. Myocardial dysplasia of the right ventricle of the heart (Uhl anomaly) as a possible cause of sudden unexpected death. Zeitschrift für Rechtsmedizin 1988;100:177-89.

37 Furanello F, Bettini R, Bertoldi A, et al. Arrhythmia patterns in athletes with arrhythmogenic right ventricular dysplasia. Eur Heart J 1989;10 (suppl D):16-9.

38 Corrado D, Thiene G, Nava A, Rossi L, Pennelli N. Sudden death in young competitive athletes: clinicopathologic correlations in 22 cases. Am J Med 1990;89:588-96.

39 Taussig HB. Defect in the musculature of the right ventricle: Parchment right ventricle. In: Taussig HB, ed. Congenital malformations of the heart. Cambridge: Harvard Univermalformations of the heart.
sity Press, 1960:138-45.

40 O'Connor WN, Cotterill CM, Marion MT, Noonan JA Defective regional myocardial development and vascularization in one variant of tricuspid atresia-clinical and necropsy findings in three cases. Cardiology in the Young 1992;2:42-52.

41 Galal O, Hentrich F, Przybilla C, Donhuijsen K. Aortenatresie und Pulmonalarterienhypoplasiebei kongenitalkorrigierter Transposition der grossen Gefaesse, Aortenisthmusstenose und Uhl's scher anomalie des linksseitigen Ventrikels. Pathologe 1987;8:168-71.

42 Hoffman JIE. Incidence, mortality and natural history. In Anderson RH, MacCartney FJ, Shinebourne EA, Tynan $M$, eds. Pediatric Cardiology. Edinburgh: Churchill M, eds. Pediatric Car

43 Thiene G, Nava A, Corrado D, Rossi L, Pennelli N. Right ventricular cardiomyopathy and sudden death in young people. N Engl J Med 1988;318:129-33.

44 Nava A, Thiene G, Canciani B, et al. Clinical profile of concealed form of arrhythmogenic right ventricular cardiomyopathy presenting with apparently idiopathic ven tricular arrhythmias. Int J Cardiol 1992;35:195-206.

45 Fontaliran F. Editorial note: further information concerning right ventricular dysplasia or right ventricular cardiomyopathy. Int J Cardiol 1992;35:207-9.

46 Dalla Volta S. Arrythmogenic cardiomyopathy of the right ventricle: thoughts of aetiology. Eur Heart J 1989;10 (suppl D):2-6.

47 Yutani $C$, Imukia $M$, Ishibashi-Ueda $H$, Nagata $S$, Sakakibara H, Nimura Y. Uhl's anomaly as a result of progression from hypertrophic cardiomyopathy. Acto Progression from hypertrophi

48 Manyari DE, Klein GJ, Gulamhussein S, et al. Arrhythmogenic right ventricular dysplasia: a generalised carmogenic right ventricular dysplasia: a
diomyopathy. Circulation 1983;68:351-7.

49 Aherne WA. Uhl's anomaly. Arch Dis Child 1973;48:160-4.

50 Ando H, Yamamato T, Tanimoto M, Ogami T, Yorifujiu S. Echocardiographic features of Uhl's anomaly. A case report. Jap Circ J 1979;43:1121-6.

51 Arcilla RA, Gasul BM. Congenital aplasia or marked hypoplasia of the myocardium of the right ventricle (Uhl's anomaly). J Pediatr 1961;58:381-8.

52 Auzépy P, Papa F, Paillas J, Manigand G, Deparis M Ventricule droit papyracé de l'adulte. Arch Mal Coeur 1975;68:657-61.

53 Buonanno C, Nidasio G, Mancuso M, Salazzari GC, Dander B, Poppi A. Ipoplasia del miocardio ventricolare destro (anomalia di Uhl) nel'adulto. G Ital Cardiol 1974; 4:200-10.

54 Calabro R. Forni N, Mininni N, Marsico F. Anomalia di Uhl. G Ital Cardiol 1977;7:189-94.

55 Descalzo A, Canadas M, Cintado C, Castillo JA, Garcia E, Ariza A. Uhl's anomaly associated with pulmonary atresia. Hum Pathol 1980;11:575-6.

56 Diaz LP, Jimenez MQ Granados FM, Martinez VP, Batres GM. Congenital absence of mygcardium of right 
ventricle: Uhl's anomaly. Br Heart J 1973;35:570-2.

57 Fuertes J, Salzar J, Mengual J, et al. Anomalie d'Uhl associée à une atresié de la valvule pulmonaire. Pediatrie 1984;39:213-7.

58 Gasul BM, Arcilla RA, Lev M. Heart disease in children. Philadelphia: JB Lippincott, 1966:751-2.

59 Haworth SG, Shinebourne EA, Miller GAH. Right-to-left interatrial shunting with normal right ventricular presHeart J 1975;37:386-91.

60 Ibsen HW, Baandrup U, Simonsen EE. Familial right ventricular dilated cardiomyopathy. Br Heart J 1985;54: 156-9.

61 Kaul U, Arora R, Rani S. Uhl's anomaly with rudimentary pulmonary leaflets. Am Heart J 1980;100:673-7.

62 Kinare SG, Panday SR, Deshmukh SM. Congenital aplasia of the right ventricular myocardium (Uhl's anomaly). Diseases of the Chest 1969;55:429-31.

63 Leproix JCM. Le ventricule droit papyracé congénital. Paris: Thése Med, 1958 (Thése No 621).

64 Montella S, Soresi V, Calo S. Absence partielle congénitale du myocarde ventriculaire droit chez le nourrisson (un du myocarde ventriculaire droit chez le nourrisson (un cadre anatomo-clinique particulie
Arch Mal Coeur 1969;8:1183-95.

65 Neimann N, Pernot C, Rauber G. Aplasie du myocarde du ventricule droit (ventricule droit papyracé congénital). Arch Mal Coeur 1965;58:421-30.

66 Novak G, Szanto PB, Gasul B, Dillom E. Congenital aplasia of the myocardium of the right ventricle. Proceedings of the Institute of Medicine of Chicago 1957;21:334-5.

67 Perrin EV, Mehrizi A. Isolated free-wall hypoplasia of the right ventricle. $A m J$ Dis Child 1965;109:558-66.

68 Segall HN. Parchment Heart (Osler). Am Heart J 1950;40: 948-50.

69 Sherman FE. An atlas of congenital heart disease. London: Henry Kimpton 1963:227 and 290.

70 Tatibouet L, Kervarec A, Balouet G. Oreillette droite et ventricule droit papyracés. Semaine des Hôpitaux des Paris ventricule droit papy

71 Zuberbuhler JR, Blank E. Hypoplasia of right ventricular myocardium (Uhl's disease). Am J Roentgenol 1970;110: 491-6.

72 Abe T, Kuribayshi R, Sato M, Nieda S, Abe S. Congenital hypoplasia of the right ventricular myocardium (Uhl's anomaly). $J$ Cardiovasc Surg 1973;14:431-8.

73 Bens JL, Quiret JC, Duboisset M, Lesbre JPH, Bernascon J. Ventricule droit papyracé: cause exeptionnelle d'adiastolie de l'adulte. Lille Médical 1973;18:157-63.

74 Bex JP, Laborde F, Lecompte Y, et al. Traitement chirurgical à coeur ouvert du ventricule droit papyracé. Ann Chir
1980;34:589-91.

75 Matsumoto Y, Yano K, Aoi W, Oku Y, Habisha K Echocardiographic evaluation of pulmonary flow pattern in Uhl's anomaly. Am Heart $J$ 1986;111:420-2.

76 Reeve R, MacDonald D. Partial absence of the right ventricular musculature-partial parchment heart. $A m J$ Cardiol 1964;14:415-9.

77 Vedel J, Frank R, Fontaine G, et al. Tachycardies ventriculaires recidivantes et ventricule droit papyracé de l'adulte. Arch Mal Coeur 1978;71:973-81.

78 Vernant P, Hazan E, Ducam H, et al. Ventricule droit papyracé. Tentative de traitment chirurgical. Ann Med Interne (Paris) 1972;123:805-16.

79 Santoli C, Palminiello A, Panzeri E, Binda G, Soresi V. L'anomalie di Uhl. Mal Cardiovascolari 1968;9:121-34.

80 Castelli C, Aiazzi L, Caprioli G, Michelucci A, Arangeli C, Dabizzi RP. Su di un caso di anomalia di Uhl. Bollettino Dabizzi RP. Su di un caso di anomalia di Ul.
Societa Italiana Cardiologia 1977;22:417-22.

81 Drory Y, Deutsch V, Shem-Tov A, Feldman S, Kariv I. L'ipoplasia del miocardio ventricolare destro (malattia di Uhl). G Ital Cardiol 1977;7:89-94

82 Dupont JC, Faton D, Perrin A. Le diagnostic clinique et hemodynamique de la maladie de Uhl chez l'adulte. Lyon Medical 1974;231:247-50.

83 Esposito L, Nobili B. Considerazioni su un caso di Progeria associato a sindrome di Uhl. Pediatr Napoli 1975; 83:326-45.

84 French JW, Baum D, Popp RL. Echocardiographic findings in Uhl's anomaly. Am J Cardiol 1975;36:349-53.

85 Morand P, Lanfranchi J, Brehier J, Laine JL, Langevin J, Raynaud $R$. Le syndrome de Uhl-Ventricule papyracé. Semaine des Hopitaux de Paris 1972;48:571-9.

86 Obma R, Perry LW, Scott LP. Uhl's anomaly of the heart with atrial septal defect and valvular pulmonary stenosis. wedical Annals of the District of Columbia 1974;43:413-8.

87 Ostermeyer J. Uhl's disease: Partial parchment right venOstermeyer J. Uhl's disease: Partial parchment right ven-
tricle. Virchows Archiv für Pathologische Anatomie 1974; 362:185-94.

88 Rashkind WJ. Atrial septostomy in congenital heart disease. In: Advances in Pediatrics. Chicago: Year Book Publications 1969:228.

89 Sugiura M, Hayashi T, Ueno K. Partial absence of the right ventricular muscle in an aged. $J p n$ Heart $J 1970 ; 11: 582-5$.

90 Tadei A, Caron J, Grimault Y, Delhumeau A. Ventricule droit papyracé de l'adulte jeune. Archives Medicales de l'Ouest 1971;3:11-20.

91 Wagner WL, Gerkens E, Grube U. Zyanotische Patientin mit rechtsventrikulaerer Dilatation und ventrikulaeren Herzrhythmusstoerungen. $Z$ Kardiol 1987;76:303-8. 